\title{
Comparative study of bacteriological examination of daily use toothbrushes stored in the bathroom and room
}

\author{
Orogu J.O.* and Ehiwario N.J. \\ Department of Science Laboratory Technology, Delta State Polytechnic Ozoro, Delta State, Nigeria.
}

Accepted 26 July, 2016

This study was carried out to investigate the presence of contaminating bacterial on regularly used toothbrush. Studies on the bacteriological quality of toothbrushes obtained from five student volunteers were carried out. The sample were coded as A1, A2, A3, A4, A5 and B1, B2, B3, B4, B5 for toothbrushes kept in the room and toothbrushes exposed in the bathroom respectively. A total of three (3) bacterial species were detected in the toothbrush, Mycobacterium spp, Streptococcus suis and Lactobacillus spp. The total heterotrophic plate count of bacterial isolates from toothbrush kept in the room ranges from $3.2 \times 103$ to $6.4 \times 103 \mathrm{Cfu} / \mathrm{ml}$ while that of toothbrush stored in the bathroom ranges from $4.0 \times 103$ to $6.0 \times 103 \mathrm{Cfu} / \mathrm{ml}$ Mycobacterium spp have the highest percentage of occurrence $(70 \%)$ while Streptococcus suis and Lactobacillus spp has the lowest occurrence $(15 \%)$. Some of the Micro-organism isolated is of public health significance. Good toothbrush hygiene is very important in the society to avoid the potential risk of infection and cross infection as good hygiene is an important factor in health.

Keywords: Bacteriological, daily use, toothbrush, bathroom, room.

\section{INTRODUCTION}

The early history and evolution of toothbrushes has its origin in the "chewing sticks" used by the Babylonians as early as 350 B.C. Ancient Greek and roman literature even discussed primitive tooth picks that were chewed which help in cleaning the tooth. As the years proceed, toothpicks grow into the chewing stick which was about the size of a modern pencil. One end was chewed into and become softened and become brushlikewise the opposite was pointed and used as a pick to clean food and debris from between the teeth. The twigs used were carefully chosen from aromatic trees that have the ability to clean and freshen the mouth.

\footnotetext{
${ }^{*}$ Corresponding author email:joshuaorogu4@gmail.com
}

The use of toothbrush in brushing teeth is the most common methods of maintaining oral hygiene. Routine tooth brushing helps clean accumulated dental plaque on the tooth surface and keep it clean and health. A toothbrush does not naturally contain nutrient to support bacterial growth. However, after brushing, food particles of cling to the bristle of the toothbrush from being rinsed with and coming into contact with the moist environment of mouth, the toothbrush will become moist. Altogether, these will help to make the toothbrush a more favorable environment for microbial growth. A new toothbrush is usually not a favorable habitat for bacteria and fungi, but in some cases, toothbrushes are already slightly infected because there is no regulation that states toothbrushes must be sold in a sterile package (Downes, 2008; Efstratiou et al., 2007).

Some microbes found in the tooth brush originated from the mouth, the contact of the tooth brush with an oral cavity will thus, causes microbes to be transferred 
to the tooth brush. In addition, a toothbrush niche can be affected by another toothbrush in close proximity. This is called cross contamination and occurs in a communal environment. A typical household uses a holder to store multiple tooth brushes, bacteria living on one toothbrush can be transferred to another nearby toothbrush in contact (Neal and Rippin, 2003 ). The same idea of bacterial transfer applies when sharing a toothbrush (Neal and Rippin, 2003 ) which is a bad hygiene practice.

The toilet or bathroom also harbors a community of microorganism that can be partially transferred into the toothbrush. The bacteria are injected from the toilet bowl after flushing.. Therefore, it advisable that individual should st ore their toothbrush in separate holder or location, preferably away from toilet (bathroom) and storing of tooth brush in close container wall cabinet because moist environment is more favourable for the growth of microorganisms to open air. Toothbrushes rapidly become heavily contaminated with oral microorganisms including bacteria, viruses and fungi (Svanbery, 1978; Kozai, 1989; Nelson et al., 2000). These include dental pathogens-such as Streptococcus mutants and Staphylococcus species.

Therefore if any individual can keep its intra-oral bacteria while using a good, sample tooth brush (medicated tooth-brush) then the qualities of life and good health can be improved with a stronger workforce. This present study focuses on the determination of; whether daily used toothbrushes harbor bacteria of medical importance, the microbial load of daily used toothbrushes and the danger of exposing toothbrushes in the bathroom and also toothbrush kept in the room.

\section{METHODOLOGY}

\section{Study area}

The study area was Ozoro, the local government headquarter of Isoko North local government area of Delta State, South-south region of Nigeria

\section{Sample collection}

The brush sample used for this study were collected in sterile container with the bristle inside the container and properly sealed with new foil paper and masking tape right inside the bath/toilet and room to avoid contamination from outside the bath/toilet and room and was transfer to the laboratory. Five (5) tooth brush with expose brittle were obtained from five (5) the different toilet/bathrooms of bed sitters and the samples were labeled B1, B2, B3, B4 and B5 and five (5) tooth brush with expose brittle were also obtained from different five (5) rooms in Ozoro, and the sample were labeled Al,
A2, A3, A4 and A5. Both were transported to the laboratory in sterile universal container where analysis was carried out.

\begin{abstract}
ANALYSIS
Using a sterile pipette, $1 \mathrm{ml}$ of the sample was pitted into a test-tube containing $9 \mathrm{ml}$ of sterile distilled water. The dilution was continued until the seventh dilution was attained for untreated water and the third dilution for treated water. Sterile and cool molten MacConkey Agar was poured ascetically into the petri dishes. Sterile pipettes were used to pipette $0.1 \mathrm{ml}$ of the sample into labeled petri dishes. A sterile spreader was used to spread the samples on the plate; the plates were then incubated in an incubator for 24 hours at $370 \mathrm{C}$. After 24 hours of incubation, the plates were examined and number colonies of the plates were counted and recorded as cfu/ml. Duplicate plates were prepared for each of the samples .Average count was recorded.
\end{abstract}

\section{Characterization of Bacteria Isolates}

The bacterial isolates on the plates were characterized based on some parameters such as the shape of the colony, edge, pigmentation, elevation, colony surface, consistency, a size and optics characteristics of different colonies observed. Various biochemical tests were carried out for further identification of the isolates and also, various staining techniques as described by Fawole and Oso (2004).

\section{RESULT AND DISCUSSION}

The bacterial isolated from the brush sample were Mycobacterium species, E. coli, Streptococcus suis and Lactobacillus species. Some bacterial isolates have shown the ability to utilize sugar as their substrate which was shown in Table 1. The prevalence rate of the organism in various groups (bathroom/toilets and rooms) showed that Mycobacterium species has the highest percentage of occurrence which is $70 \%$ while the lowest is Streptococcus species and Lactobacillus which is $15 \%$ for each as shown in table 2 . Table 3 Shows, bacterial isolates coli form count, while table 4 Shows, total bacterial count from samples

\section{DISCUSSION}

This study has revealed the presence of bacterial spcies such as Mycobacterium spp., Streptococcus suis, and Lactobacillus spp., on toothbrushes which is similar to other finding elsewhere (Glass et al., 1986; 
Table 1: Cultural, Morphological and Biochemical Characteristic of Bacteria Isolates.

\begin{tabular}{|c|c|c|c|c|c|c|c|c|c|c|}
\hline 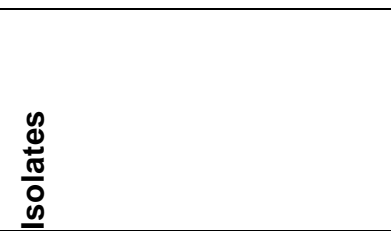 & 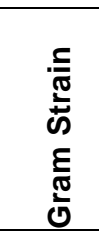 & 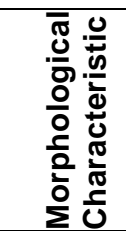 & 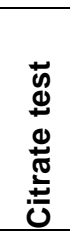 & 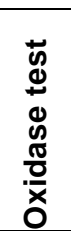 & 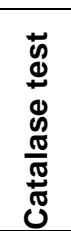 & $\begin{array}{l}\overline{\mathscr{d}} \\
\stackrel{+}{0} \\
\stackrel{0}{0} \\
\stackrel{0}{0}\end{array}$ & 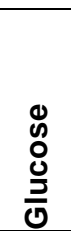 & 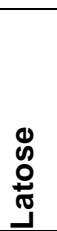 & $\begin{array}{l}\text { N } \\
\text { T }\end{array}$ & 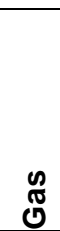 \\
\hline $\bar{M}$ ycobacterium species & $G P B$ & Rods & + & - & + & $=$ & + & + & - & - \\
\hline Streptococcus suis & $G P C$ & Cocci & + & - & + & - & + & + & - & - \\
\hline Lactobacillus species & $G P B$ & Rod & - & - & + & - & + & + & + & - \\
\hline
\end{tabular}

Key $=+$ positive, $=$ Negative, GPB $=$ Gram Positive Bacillus, GNB $=$ Gram

Negative Bacillius, GPC = Gram Positive Cocci

Table 2: Occurrence Rate and percentage of isolates in the Samples

\begin{tabular}{lcc}
\hline Bacterial Isolates & Number of occurrence & $\%$ Occurrence \\
\hline Mycobacterium species & 7 & $70 \%$ \\
Streptococcus suis & 2 & $15 \%$ \\
Lactobacillus species & 2 & $15 \%$ \\
\hline
\end{tabular}

Table 3: Bacterial Isolates Coli form Count

\begin{tabular}{lccc}
\hline Sample & Bacterial Isolates & Number of occurrence & Cfu/ml \\
\hline A & Mycobacterium species & 5 & 32 to 64 \\
B & Streptococcus suis & 2 & 44 \\
& Lactobacillus species & 2 & 52 to 60 \\
& Mycobacterium species & 2 & 40 to 48 \\
\hline
\end{tabular}

Table 4: Total bacterial count form samples

\begin{tabular}{lcc}
\hline Sample & Bacteria Isolates & CFU/ML \\
\hline A & Mycobacterium species & $3.2 \times 103$ \\
& $4.0 \times 103$ & $5.2 \times 103$ \\
& $6.4 \times 103$ & $3.6 \times 103$ \\
& " & $4.0 \times 103$ \\
B & Mycobacterium species & $6.0 \times 103$ \\
& Lactobacillus species & $4.0 \times 103$ \\
& Streptococcus suis & $4.8 \times 103$ \\
&
\end{tabular}

Taji and Rogers 1998 and Jagadeeshwar et al., 2015). Lactobacillus species was also identified by ArbabiKalati et al., 2014. Therefore, it is possible that these bacterial were transferred when daily product that carry these species which are commonly associated with food are been eaten. Some of these bacterial that have been found to be associated with toothbrush can cause or contribute to general somatic health problem involving the heart, kidney, livers, pregnancy and respiratory disorders etc if oral hygiene's is not well 
maintained. (Bayraktar et al., 2009). Another aspect is the $\mathrm{pH}$ condition, some bacteria can survive in the bristle of the expose toothbrush in the bathroom, and toothbrush kept in the room. Most of these bacterial comes from the mouth and they are conditioned to survive a wide range of $\mathrm{pH}$ level environment. In addition, the application of toothpaste can also disrupt the community, but at the same time has a mineral effect on those bacterial. The $\mathrm{pH}$ condition where some of these bacterial can survive is 7.0 , but the $\mathrm{pH}$ level can change again if the toothbrush is thoroughly washed with clean water causing the $\mathrm{pH}$ level to fall within $6.0-8.0$ and once the toothbrush dries the bacterial that would normally not survive within $\mathrm{pH}$ of $6.0-8.0$ will die off. Keeping of toothbrush in the bathroom is improper because the toilets also harbor a community of bacteria that can be partially transferred into the toothbrush and these bacterial can also be infected from the toilet brush kept in the toilet causing the bristle of the toothbrush to be a favorable place to survive. The best storage method of toothbrush is the keeping of toothbrush in the room, in a standard toothbrush pack. The room is less contaminated with microorganism compared to the toilet where the disposal of waste takes place. The room has free air ventilation compared to the toilet where the highest concentration of microorganism exists, due to the evaporation of micro-organism during flushing.

From the analysis of this study, only Mycobacterium species was found in the toothbrushes kept in the room while the toothbrushes exposed in the bathroom where Mycobacterium species, Lactobacillus species and Streptococcus suis hence the storage of toothbrush in the room with standard toothbrush pack is highly recommended.

\section{Conclusion}

This study has revealed the presence of bacteria isolates such as Mycobacterium spp, Streptococcus suis and Lactobacillus spp, were found thus, individual should maintain their oral and dental health at a high level to avoid any of these somatic problems. The best place for storing toothbrush is in the room in a standard toothbrush pack because the room is less contaminated with microorganism, has a free air ventilation and does, not harbor more micro organism compared to the toilet where disposal of waste take place and the highest concentration of microorganism can be found.

\section{Recommendation}

It is recommended that people should stop the storage of toothbrush in the bathroom; they should change their toothbrush frequently and / or use a proprietary toothbrush disinfectant. Also storing of toothbrush closed to other toothbrushes may lead to transfer of bacterial, therefore it should be avoided.

\section{REFERENCES}

Arbabi-Kalati K, Nosratzehi T, Farhadmollashahi L, Asadi IM, Bameri Z (2014). Evaluation of relationship between toothbrush keeping method and its microbial content. Caspian J. Dent. Res. 3:26-31.

Bayraktar G, Kurtulus I, Kazangoglu RI, Cintan S, Bural C, Bozpakioglu S, Issever H, Yildiz A (2009). Oral health and inflammation in patients with end-stage Renal failure. Perit dial.Int. 29(4):472-479.

Downes J, Hooper SJ, Wilson MJ, Wade WG (2008). Prevotella histolitica sp. nov. , isolated from the human oral cavity. International Journal of Systematic and Evolutionary Microbiology. 58 (8):1788-1791.

Efstratiou M, Papaioannou W, Nakou M, Ktenas E, Vrotsos I, Panis V (2007). Contamination of a toothbrush with antibacterial properties by oral microorganisms. Journal of Dentistry 35: 331-337.

Fowole FO, Oso BA (2004). Laboratory Manual of Microbiology $\left(4^{\text {th }}\right.$ Edition). Spectrum Books Limited, Ibadan pp 16-80

Jagadeeshwar RS, Byalakere RC, Nova H, Gujjarlapudi SK, Irrukula VR, Lingam JL, Sanka P, Durga, V (2015). Microbial Contamination of Tooth Brushes Stored in Different Settings before and after Disinfection with Chlorhexidine- A Comperative Study. J. of Young Pharm. 7(4):486-492.

Kozai K, Iwai T, Miura K (1989). Residual Contamination of tooth brushes by Microogranism. Journal of Dentistry for children. 56:210-214

Neal PR, Rippin JW (2003). The efficiency of a toothbrush Disinfectant spray: an In -vitro study. Journal of dentistry. 31:153157.

Nelson FP, Macari S, Faria G, Assed S, Ito IY (2000). Microbial contamination of toothbrushes and their decontamination. Paediatric Dentistry 22(5): 381-384

Svanbery M (1978). Contamination of toothpaste and toothbrush by Streptococcus mutans. Scand. J. of Dent. Res. 86:412-414.

Taji SS, Rogers AH (1998).The microbial contamination of toothbrushes. A pilot study. Australian Dental Journal 43: 128-130. 